\title{
Assessment of Physicochemical Quality of Sediment from Kolo Creek, Niger Delta
}

\section{OGAMBA Emmanuel N.*1 and NWABUEZE Ebere ${ }^{2}$}

${ }^{1}$ Department of Biological Sciences, Faculty of Science, Niger Delta University, Bayelsa State, Nigeria.

${ }^{2}$ Department of Animal and Environmental Biology, Rivers State University of Science and Technology, Nkpolu, Port Harcourt, Nigeria.

\section{ARTICLE INFO}

Article No.: 021017023

Type: Research

DOI: 10.15580/GJBS.2017.2.021017023

Submitted: $10 / 02 / 2017$

Accepted: 18/02/2017

Published: 27/02/2017

*Corresponding Author

Emmanuel N. Ogamba

E-mail: emmaogamba @gmail.com
This study investigated the physicochemical characteristics of sediment from Kolo creek, Niger Delta Nigeria. The samples were collected between August to September 2015 and analyzed using standard procedures. Results showed that $\mathrm{pH}$, conductivity, total Nitrogen, total organic Carbon, total Hydrocarbon, Calcium, Potassium, Sodium, Magnesium, Nitrate, Phosphate, Sulphate and Chloride concentration of the sediments ranged from $6.74-6.82,228.32-225.03 \mu \mathrm{Scm}^{-1}, 5.36$ $6.01 \%, 6.00-6.42 \%, 6.66-7.00 \%, 10.23-11.12 \mathrm{mg} / \mathrm{kg}, 6.66-7.33 \mathrm{mg} / \mathrm{kg}$, $8.63-9.31 \mathrm{mg} / \mathrm{kg}, 4.27-5.08 \mathrm{mg} / \mathrm{kg}, 6.03-6.82 \mathrm{mg} / \mathrm{kg}, 4.77-5.62 \mathrm{mg} / \mathrm{kg}$, $5.89-7.66 \mathrm{mg} / \mathrm{kg}$ and $5.96-6.31 \mathrm{mg} / \mathrm{kg}$ respectively. Analysis of variance showed that there are no significant variations $(P>0.05)$ among the locations for each of the parameters. High concentration of nutrients (cations and anions) suggests the influence of anthropogenic activities on the sediment quality of Kolo creek.

Keywords:

Environmental Contaminants, Kolo creek, Physico-chemical assessment, Surface water 


\section{INTRODUCTION}

The Niger Delta region is one of the most productive regions in Nigeria. The region has several square kilometers of wetland, surface water, oil and gas facilities. As such, the region contributes significantly to Nigeria's foreign earnings. Besides oil and gas facilities, the region has several biodiversity including aquatic and terrestrial mammals, aves and reptiles and medicinal plants. Several plant species found in the region have medicinal properties including antimicrobial, antioxidants, pest repellent among others. However, probably due to over exploitation most of the biodiversity are threatened with some gone on extinction.

Due to industrialization and urbanization, the rate of environmental pollution has increased. Environmental contaminants are majorly caused by human activities and to a lesser extent natural effects (Ogamba et al., 2016). Also, it appears that human activities on the ecosystem are increasingly leading to environmental pollution (Izah et al., 2015). Among the environmental pollutants, the aquatic ecosystem appears to be the major recipient of both natural and human induced environmental pollutants. This is because soil and air - based contaminants could also be deposited in the surface water after precipitation via runoff.

The constituents of substances that could contaminate the environment determine its impacts. Most substances that cause environmental pollution especially in the aquatic ecosystem have physical, biological and chemical characteristics. Human activities on the water ways including swimming, fishing, boating/water transportation etc., affect the quality of the water and its associated sediments.

Sediments are earth materials such as sand, clay, silt that settles at the bottom of the water bodies. They are derived from several materials including decaying plants and animals, weathering processes, waste materials deposited on the surface water. Depending on the sediment characteristics or composition, it can either appear as suspended or deposited form.

Several water bodies exist in the Niger Delta. The characteristics of the water bodies have been severally reported in literature. For instance, in Bayelsa state some of the rivers that have been studied include River Nun (Agedah et al., 2015; Ogamba et al., 2015a), Ikoli creek (Ogamba et al., 2015b; Seiyaboh et al., 2016a), Kolo creek (Ogamba et al., 2015c) Sagbama creek (Seiyaboh et al., 2017a), Efi lake (Angaye and Mieyepa, 2015), Epie creek (Izonfuo and Bariweni, 2001) among others. Since these water bodies contain sediments, its quality has not been assessed as the water itself. Among the few studies that have been carried out on the sediment of water bodies in Bayelsa state are the works of Seiyaboh et al. (2017b) on Sagbama creek, Seiyaboh et al. (2016b) on Epie creek and Seiyaboh et al. (2016b) on Ikoli creek. Information about the sediment physico-chemical quality is scanty in literature. As such, this present study investigates the physiochemical quality of sediments from Kolo creek, Niger Delta region of Nigeria.

\section{MATERIALS AND METHODS}

\section{Study Area}

Kolo creek transverse through several communities; Otuasaga, Oruma, Imiringi (Ineginte et al., 2010), Amurukani, Kolo 1, Kolo 2, Kolo 3, Emeyal 1, Emeyal 2 etc. Kolo creek is a non-tidal fresh water that has been urbanised and industrialized due to the presence of oil and gas infrastructure in the area (Ineginte et al., 2010). Other economic activities carried out around Kolo creek include fishing, dredging, boating etc. Kolo creek is a major recipient of effluents from several anthropogenic activities (Ineginte et al., 2010), and a breeding ground for several fish species (Seiyaboh et al., 2016a). Kolo creek shares similar climatic conditions with other areas around Bayelsa state. Furthermore, the climatic condition of different areas in Bayelsa state has been widely reported in literatures by authors (Seiyaboh et al., 2016a-c, 2017a,b; Ogamba et al., 2015a-c, 2017; Agedah et al., 2015; Aghoghovwia and Ohimain, 2014).

\section{Sample collection and preparation}

Triplicate sediment samples were obtained from three locations along Kolo creek including Kolo, Imiringi and Otusega using sediment grab in August to September 2015. The samples were properly labeled and packaged with aluminum foil. The samples were shade - dried and sieved using mesh prior to analysis.

\section{Physico-chemical analysis of the sediment}

The various parameters were analyzed based on standard analytical procedure previously described in literatures. Total hydrocarbon content was analyzed using ASTM D 9071B - 7 (Soxhlet Extraction Method) previously described by Aigberua et al. (2016a) and conductivity were analyzed based on the method described by Aigberua et al. (2016b). Other analytical procedures were employed for other parameters which include nitrate, sulphate, phosphate (Dewis and Freitas, 1970), calcium, potassium, sodium, magnesium (Nwakaudu et al., 2012), pH (Bates, 1954), organic carbon (Akubugwo et al., 2007; Osuji and Adesiyan, 2005) and nitrogen (Udoh and Ogunwale, 1986).

\section{Statistical Analysis}

Statistical analysis was carried out using SPSS. Data was expressed as mean \pm standard error. One way 
analysis of variance was used to show significance difference at $\mathrm{P}=0.05$, and Duncan multiple range test statistics was used to show source of the observed difference.

\section{RESULTS AND DISCUSSION}

Table 1 presents some of the physico-chemical properties of the sediment samples from Kolo creek, Niger Delta Nigeria. The $\mathrm{pH}$, conductivity, total nitrogen, total organic carbon and total hydrocarbon concentration ranged from $6.74-6.82,228.32-225.03 \mu \mathrm{Scm}^{-1}, 5.36$ $6.01 \%, 6.00-6.42 \%$ and $6.66-7.00 \mathrm{mg} / \mathrm{kg}$ respectively. The concentration of calcium, magnesium, sodium and potassium ranged from $10.23-11.12 \mathrm{mg} / \mathrm{kg}, 6.66-$
$7.33 \mathrm{mg} / \mathrm{kg}, \quad 8.63 \quad-9.31 \mathrm{mg} / \mathrm{kg}$ and 4.27 - 5.08 respectively. Nitrate, Phosphate, Sulphate and Chloride concentration ranged from $6.04-6.82 \mathrm{mg} / \mathrm{kg}, 4.77-5.62$ $\mathrm{mg} / \mathrm{kg}, \quad 5.90-7.66 \mathrm{mg} / \mathrm{kg}$ and $5.96-6.31 \mathrm{mg} / \mathrm{kg}$ respectively. There was no significant variation $(P>0.05)$ in the different locations for each of the parameters. Lack of variations among the various locations for each of the parameters studied is an indication that the anthropogenic natural activities in the locations the samples were obtained from were basically the same. Higher nutrient (cations and anions) could be due to runoff resulting from rainfall. Wastes discharge into the water could also settle at the bottom of the surface water to form sediment (Seiyaboh et al., 2017b). High concentration of total hydrocarbon content suggests the effects of oil field facilities in Kolo creek.

Table 1: Physiochemical properties of sediment samples from the study area

\begin{tabular}{|l|r|r|r|}
\hline Parameters & Station 1 & Station 2 & Station 3 \\
\hline $\mathrm{pH}$ & $6.82 \pm 0.42 \mathrm{a}$ & $6.74 \pm 0.11 \mathrm{a}$ & $6.75 \pm 0.05 \mathrm{a}$ \\
\hline Conductivity, $\mu \mathrm{Scm}^{-1}$ & $234.33 \pm 36.14 \mathrm{a}$ & $228.32 \pm 35.59 \mathrm{a}$ & $225.03 \pm 34.20 \mathrm{a}$ \\
\hline Total nitrogen, \% & $6.01 \pm 1.54 \mathrm{a}$ & $5.78 \pm 1.88 \mathrm{a}$ & $5.36 \pm 1.73 \mathrm{a}$ \\
\hline Total organic carbon, \% & $6.42 \pm 0.67 \mathrm{a}$ & $6.23 \pm 0.49 \mathrm{a}$ & $6.00 \pm 0.36 \mathrm{a}$ \\
\hline Total hydrocarbon, $\mathrm{mg} / \mathrm{kg}$ & $7.00 \pm 0.99 \mathrm{a}$ & $7.18 \pm 0.81 \mathrm{a}$ & $6.66 \pm 0.75 \mathrm{a}$ \\
\hline Nitrate, $\mathrm{mg} / \mathrm{kg}$ & $6.82 \pm 0.09 \mathrm{a}$ & $6.29 \pm 0.25 \mathrm{a}$ & $6.03 \pm 0.32 \mathrm{a}$ \\
\hline Phosphate, $\mathrm{mg} / \mathrm{kg}$ & $5.62 \pm 0.41 \mathrm{a}$ & $5.16 \pm 0.47 \mathrm{a}$ & $4.77 \pm 0.46 \mathrm{a}$ \\
\hline Sulphate, $\mathrm{mg} / \mathrm{kg}$ & $7.66 \pm 0.11 \mathrm{a}$ & $6.36 \pm 0.53 \mathrm{a}$ & $5.90 \pm 0.46 \mathrm{a}$ \\
\hline Chloride, $\mathrm{mg} / \mathrm{kg}$ & $6.31 \pm 0.24 \mathrm{a}$ & $6.27 \pm 0.24 \mathrm{a}$ & $5.96 \pm 0.14 \mathrm{a}$ \\
\hline Calcium, $\mathrm{mg} / \mathrm{kg}$ & $10.23 \pm 5.45 \mathrm{a}$ & $10.57 \pm 5.49 \mathrm{a}$ & $11.12 \pm 5.70 \mathrm{a}$ \\
\hline Magnesium, $\mathrm{mg} / \mathrm{kg}$ & $6.66 \pm 0.58 \mathrm{a}$ & $6.88 \pm 0.64 \mathrm{a}$ & $7.33 \pm 0.58 \mathrm{a}$ \\
\hline Sodium, $\mathrm{mg} / \mathrm{kg}$ & $8.63 \pm 0.56 \mathrm{a}$ & $8.91 \pm 0.64 \mathrm{a}$ & $9.31 \pm 0.70 \mathrm{a}$ \\
\hline Potassium, $\mathrm{mg} / \mathrm{kg}$ & $4.27 \pm 0.27 \mathrm{a}$ & $4.67 \pm 0.35 \mathrm{a}$ & $5.08 \pm 0.36 \mathrm{a}$ \\
\hline
\end{tabular}

Data is expressed as mean \pm Standard deviation; the same letters across the row is not significantly different $(P>0.05)$ according to Duncan Multiple Range Test (DMRT) statistics

The values observed in this study has most of its parameters higher than the values previously reported in sediments in other surface water in Bayelsa state. Seiyaboh et al. (2016b) reported $\mathrm{pH}(6.67-6.77)$ total nitrogen (2.64-9.20\%) which is close to the values of this study, conductivity (435.17- $\left.1189.50 \mu \mathrm{hmoscm}^{-1}\right)$ which is higher than the values of this study, and nitrate $(2.87-7.59 \mathrm{mg} / \mathrm{kg})$, sulphate $(1.06-3.81 \mathrm{mg} / \mathrm{kg})$, (phosphate $\quad(0.09-\quad 0.42 \mathrm{mg} / \mathrm{kg})$, calcium $(3.92-$ $6.88 \mathrm{mg} / \mathrm{kg})$, magnesium $(2.46-4.82 \mathrm{mg} / \mathrm{kg})$, sodium $(2.18$ - $4.82 \mathrm{mg} / \mathrm{kg})$, potassium $(1.59-3.34 \mathrm{mg} / / \mathrm{kg})$, total organic carbon (8.48- $22.54 \%$ ) and total hydrocarbon content $(1.20-4.68 \mathrm{mg} / \mathrm{kg})$ which were lower than the values of this present studies. Seiyaboh et al. (2016c) also reported physicochemical quality of sediments from Ikoli creek to have values of $6.46-7.25(\mathrm{pH})$ and 134.33
- 600.00uhmoscm ${ }^{-1}$ (Conductivity) which are within the values obtained in this study, $2.11-3.15 \mathrm{mg} / \mathrm{kg}$ (nitrate), $0.13-0.39 \mathrm{mg} / \mathrm{kg}$ (phosphate), $0.28-1.31 \mathrm{mg} / \mathrm{kg}$ (sulphate), 2.53- 6.76mg/kg (calcium), $1.07-1.76 \mathrm{mg} / \mathrm{kg}$ (potassium), $1.07-2.84 \mathrm{mg} / \mathrm{kg}$ (sodium), $1.21-3.82$ $\mathrm{mg} / \mathrm{kg}$ (magnesium), 2.31- $6.81 \mathrm{mg} / \mathrm{kg}$ (total hydrocarbon) and $3.35-8.27 \%$ (organic carbon) which is lower than the values obtained in this present study. Seiyaboh et al. (2017b) reported sediments from Sagbama creek to have a value of $6.73-6.87,423.53-$ $2033.56 \mu \mathrm{hmoscm}^{-1}, 2.43-4.57 \mathrm{mg} / \mathrm{kg}, 1.30-$ $4.20 \mathrm{mg} / \mathrm{kg}, 2.43-5.10 \mathrm{mg} / \mathrm{kg}, 4.04-6.20 \mathrm{mg} / \mathrm{kg}, 4.77-$ $6.12 \mathrm{mg} / \mathrm{kg}, 4.21-8.62 \mathrm{mg} / \mathrm{kg}, 1.65-2.80 \mathrm{mg} / \mathrm{kg}, 3.35-$ $5.50 \%$ and $6.73-10.73 \%$ for $\mathrm{pH}$, conductivity, nitrate, sulphate, phosphate, calcium, magnesium, sodium, potassium, total nitrogen and organic carbon. Among the 
parameters determined by Seiyaboh et al. (2017b), potassium, calcium, sulphate, nitrate were lower compared to the findings of this study, while sodium, magnesium, phosphate, total organic carbon and $\mathrm{pH}$ were close to the values recorded in this study. Differences in the physicochemical quality of the sediments from this study compared to previous studies could be attributed to variation in anthropogenic activities carried out in the different water bodies. Typically, sediment quality of water bodies is influenced by human activities and natural effects. Since the study area compared and literature values used for comparison (Sagbama creek, Epie creek and Ikoli creek) has similar climatic requirements. As such the variation is due to human activities.

\section{CONCLUSIONS}

The Niger Delta region of Nigeria has several surface water in different sizes including river, pond, creeks, lake, creeklets, stream etc. Surface water are the major recipient of environmental contaminants, which are washed into the water through runoff resulting from precipitation. This study assessed the physico-chemical quality of sediments from Kolo creek. Results showed that the sediment of the creek is high in nutrient (cations and anions), which suggested the effect of runoff and anthopogenic activities in the creek. The concentration of total hydrocarbon content were high indicating the impacts of oil field facilities along Kolo creek. Since surface water contains sediments, which act as habitat to several benthic organisms. Therefore, it is necessary to assses the concentration of minerals and other possible contaminants of surface water and sediment to avoid potential effect on organisms found in surface water and its sediment.

\section{REFERENCES}

Agedah, E.C., Ineyougha, E.R., Izah, S.C., and Orutugu, L.A. (2015). Enumeration of total heterotrophic bacteria and some physico-chemical characteristics of surface water used for drinking sources in Wilberforce Island, Nigeria. Journal of Environmental Treatment Techniques, 3(1): $28-34$.

Aghoghovwia, O. A. and Ohimain, E. I. (2014). Physicochemical characteristics of lower Kolo creek, Otuogidi, Bayelsa state. Nigerian Journal of Agriculture, Food and Environment, 10(1):23 - 26.

Aigberua, A.O., Ekubo, A.T., Inengite, A.K. and Izah, S.C. (2016a). Evaluation of total hydrocarbon content and polycyclic aromatic hydrocarbon in an oil spill contaminated soil in Rumuolukwu community in Niger Delta. Journal of Environmental Treatment Techniques, 4(4): $130-142$.

Aigberua, A.O., Ekubo, A.T., Inengite, A.K. and Izah, S.C. (2016b). Seasonal variation of nutrient composition in an oil spill contaminated soil: a case of Rumuolukwu, Eneka, Port Harcourt, Nigeria. Biotechnological Research, 2(4):179-186.

Akubugwo, I.E., Ofoegbu, C.J. and Ukuoma, C.U. (2007). physiochemical studies on Uburu salt lake, Ebonyi State Nigeria. Pakistan Journal of Biological Sciences, 10(18):3170-3174

Angaye, T.C.N. and Mieyepa, C.E. (2015). Assessment of Elemental and Microbial Quality of Lake Efi In Bayelsa State, Central Niger Delta, Nigeria. Journal of Environmental Treatment Techniques, 3(2): 71 75.

Bates, R.G. (1954). Electrometric pH determinations John Willey and Sons Inc. New York.

Dewis, J. and Fretias, F. (1970). Physical and Chemical Methods of Soil and water analysis. Soil Bulletin 10. FAD ROME.

Inengite, A. K., Oforka, N. C. and Osuji, L.C. (2010). Survey of heavy metals in sediments of Kolo creek in the Niger Delta, Nigeria. African Journal of Environmental Science and Technology, 4(9):558566.

Izah, S.C., Angaye, T.C.N. and Ohimain, E.I. (2015). Climate change: some meteorological indicators and perception of farmers in Yenagoa metropolis, Bayelsa state, Nigeria. International Journal of Geology, Agriculture and Environmental Sciences. 3(1): $56-60$.

Izonfuo, L.W.A. and Bariweni, A. P. (2001). The effect of urban runoff water and human activities on some physico-chemical parameters of the Epie Creek in the Niger Delta. Journal of Applied Sciences and Environmental Management, 5(1):47-55.

Nwakaudu, M.S., Kamen, F.L., Afube, G., and Nwakaudu, A.A., Ike, I.S. (2012). Impact of Cassava Processing Effluent on Agricultural Soil: A Case Study of Maize Growth. Journal of Emerging Trends in Engineering and Applied Sciences, 3(5): 881-885

Ogamba EN, Izah SC and Oribu T. (2015a). Water quality and proximate analysis of Eichhornia crassipes from River Nun, Amassoma Axis, Nigeria. Research Journal of Phytomedicine, 1(1): $43-48$.

Ogamba, E.N., Izah, S.C. and Toikumo, B.P. (2015b). Water quality and levels of lead and mercury in Eichhornia crassipes from a tidal creek receiving abattoir effluent, in the Niger Delta, Nigeria. Continental Journal of Environmental Science, 9(1): $13-25$.

Ogamba, E.N., Seiyaboh, E.I., Izah, S.C., Ogbugo, I. and Demedongha, F.K. (2015c). Water quality, phytochemistry and proximate constituents of Eichhornia crassipes from Kolo creek, Niger Delta, Nigeria. International Journal of Applied Research and Technology, 4(9): $77-84$.

Ogamba, EN, Izah SC and Omonibo E. (2016). Bioaccumulation of hydrocarbon, heavy metals and minerals in Tympanotonus fuscatus from coastal region of Bayelsa state, Nigeria. International Journal of Hydrology Research. 1: 1-7. 
Ogamba, E.N., Ebere, N. Izah, S.C. (2017). Heavy metal concentration in water, sediment and tissues of Eichhornia crassipes from Kolo creek, Niger Delta. Greener Journal of Environmental Management and Public Safety, In press.

Osuji, L.C. and Adesiyan, S.O. (2005). The Isiokpo oil pipeline leakage. Total organic carbon/organic matter contents of affected soils. Chemical Biodiversity 2: 1079-1085.

Seiyaboh, E.I., Izah, S.C. and Okogbue, B.C. (2016a). Seasonal Variation in Length-Weight Relationship and Condition Factor of Five Fish Species from Kolo Creek, Niger Delta. Greener Journal of Agricultural Sciences, 6(11): $342-348$.

Seiyaboh, E.I., Inyang, I.R. and Izah, S.C. (2016b). Spatial Variation in Physico-chemical Characteristics of Sediment from Epie Creek, Bayelsa State,
Nigeria. Greener Journal of Environment Management and Public Safety, 5(5): $100-105$.

Seiyaboh, E.I., Inyang, I.R. and Izah, S.C. (2016c). Seasonal Variation of Physico-Chemical Quality of Sediment from Ikoli Creek, Niger Delta. International Journal of Innovative Environmental Studies Research, 4(4): 29-34.

Seiyaboh, E.I., Izah, S.C. and Oweibi, S. (2017a). Assessment of Water quality from Sagbama Creek, Niger Delta, Nigeria. Biotechnological Research, $3(1): 3(1): 20-24$

Seiyaboh, E.I., Izah, S.C. and Oweibi, S. (2017b). Physico-chemical Characteristics of Sediment from Sagbama Creek, Nigeria. Biotechnological Research, 3(1): 25-28

Udoh JE, Ogunwale LM. 1986. Laboratory Manual for analysis of soil, plant and water samples. University Press Ibadan 151-162.

Cite this Article: Ogamba EN and Nwabueze E (2017). Assessment of Physicochemical Quality of Sediment from Kolo Creek, Niger Delta. Greener Journal of Biological Sciences, 7(2):020-024, http://doi.org/10.15580/GJBS.2017.2.021017023. 